\title{
Examining the Relationships between Destination Image, Place Attachment, and Destination Loyalty in the Context of Night Markets
}

\author{
Yu-Jen Chiang ${ }^{1}$ \\ ${ }^{1}$ Department of Cultural Resources and Leisure Studies, National Taitung University, Taiwan \\ Correspondence: Yu-Jen Chiang, Department of Cultural Resources and Leisure Studies, National Taitung \\ University, Taiwan. E-mail: kchiang@nttu.edu.tw
}

Received: November 9, 2015

Accepted: December 3, 2015 Online Published: January 23, 2016

doi:10.5539/ijbm.v11n2p11

URL: http://dx.doi.org/10.5539/ijbm.v11n2p11

\begin{abstract}
This study investigates destination image, place attachment (including place dependence and place identity), and destination loyalty among visitors to night markets. A total of 474 effective questionnaires were collected from visitors to the three well-known Tainan night markets in Taiwan. Confirmatory factor analysis and structural equation modeling were employed using Amos 18 for Windows. The empirical results showed that destination image has a significant direct effect on place dependence, place identity, and destination loyalty. Additionally, place identity is the antecedent that has an effect on destination loyalty. In the indirect effect, destination image mainly influenced destination loyalty through place identity. Practical implications and recommendations for further studies are also provided.
\end{abstract}

Keywords: night market, destination image, place attachment, destination loyalty

\section{Introduction}

Night markets provide people with opportunities for dining, shopping, entertainment, performances, and strolling at night. In many Asian countries, such as Hong Kong, Macau, China, Singapore, Indonesia, Thailand, Malaysia, and Taiwan, night markets are ubiquitous (Latif \& Barua, 2012).

In Taiwan, night markets are a popular setting where many individuals spend their free time and engage in activities at night. In general, the main features of night markets in Taiwan include flexible use of time, friendly and relaxed atmosphere, diversified and cheap shopping and dining options, and presentation of local cultural characteristics (Huang, Liou, \& Tzeng, 2009). According to the 2014 Survey of Travel by R.O.C Citizens, conducted by the Tourism Bureau, Ministry of Transportation and Communications, Republic of China (2015a), three of the country's most visited destinations in 2014 were night markets. In addition, night markets were one of the major scenic spots inbound visitors visited in 2014 (Tourism Bureau, MOTC, 2015b). Clearly, night markets are not only a source of recreation for local residents but also an important tourism resource in Taiwan. Furthermore, understanding of the behavioral model of visitors to night markets can help to enhance their marketing management.

Many previous studies have indicated that the tourism image affects tourist behavior (Baker \& Crompton, 2000; Chen \& Tsai, 2007). Additionally, Niininen and Riley (2004) and Oppermann (2000) pointed out that establishing loyalty is beneficial, and even critical, to the marketing management of destinations. Apparently, both destination image and loyalty are valuable variables in the understanding of behavioral model of visitors (Qu, Kim, \& Im, 2011; Chen, Yeh, \& Huan, 2014). Therefore, this study examines the relationship between the destination image and destination loyalty of visitors to night markets.

Huang et al. (2009) indicated that past studies on night markets mainly focused on visitor preferences, motivations, and improvements to service quality. However, night markets are strongly characterized by the experiences of leisure and consumption. Therefore, we argue that the traditional information-processing model, which emphasizes rational decision making, is insufficient for investigating the behavior of visitors to night markets. Moreover, visitors' perceived experience can be derived from both personal and environmental factors as well as symbolic meaning and affective response. This notion supports the viewpoint of Bricker and Kerstetter (2000), who demonstrated that place attachment represents an individual's functional dependence on a place and is associated with emotional identity. However, night markets have largely been ignored in studies of place 
attachment. This is somewhat surprising, as night markets reflect the local cultural and social characteristics of many Asian countries. Based on these studies, we aim to investigate the role of place attachment in the context of night markets.

The existing studies have indicated that image affects revisit intention/loyalty (Yoon \& Uysal, 2005; Choi, Tkachenko, \& Sil, 2011; Chen, Yeh, \& Huan, 2014) and visitors' place attachment to a destination (Lee, 2001; Veasna, Wu, \& Huang, 2013). In addition, place attachment has been shown as a major precedent of loyalty (Alexandris, Kouthouris, \& Meligdis, 2006; Yüksel et al., 2010). Given that place attachment is of great importance to destination image and loyalty. Consequently, this study synthesizes previous studies and postulates that individuals visiting a given night market will develop a specific complex image during their visit. Moreover, both cognitive evaluation and affective appraisals will be continually produced to form connection with a given night market during the process of destination image formation. Over time, they may develop place dependence if the services or products provided by the night market meet their needs. Also, visitors may develop a social association and emotional identity when they spend a lot of time at the market, which may encourage visitors' loyalty. However, few studies examine the role of place attachment dimensions (composed of place dependence and place identity) in the relationship between destination image and loyalty. Additionally, exactly how destination image, place attachment, and loyalty are related has seldom been simultaneously examined in the night market context.

Therefore, the main purpose of this study is to investigate how destination image affects visitors' place attachment (composed of place dependence and place identity) and eventually influence visitors' destination loyalty in the night market context. The results of this study are expected to be useful in developing effective marketing strategies and sustainable operations for night markets.

\section{Literature Review and Research Hypotheses}

The proposed conceptual model of this study is constructed on the basis of the "perception $\rightarrow$ attitude $\rightarrow$ intention" process in cognitive psychology (Oliver, 1980). Destination image is considered to be the construct of perception (Crompton, 1979; Dadgostar \& Isotalo, 1992), place attachment as the construct of attitude (Jorgensen \& Stedman, 2001; Kyle et al., 2004), and loyalty as the construct of intention. Additionally, in the following subsections, these constructs are further elucidated, and the relationships between these constructs are discussed.

\subsection{Destination Image}

Existing research suggests that destination image comprises an individual's impressions, beliefs, thoughts, perceptions, and feelings about a specific destination (Crompton, 1979; Baloglu \& McCleary, 1999). Numerous academic studies have confirmed the influence of destination image on the decision-making process of visitors (Birgit, 2001; Beerli \& Martin, 2004; Chen \& Tsai, 2007; Chen et al., 2014). There is a general agreement among researchers that destination image should be interpreted through both cognitive evaluation and affective appraisals (Baloglu \& Brinberg, 1997; Baloglu \& McCleary, 1999; Beerli \& Martin, 2004).

Lee et al. (2008) applied the concept of complex images to investigate the impressions of night markets held by temporary residents and foreign tourists in Taiwan. Through exploratory factor analysis, they showed that the images of night markets can be divided into food and local specialties, atmosphere, public facilities, environment, products, price, bargains, and reputation. Wu (2011) investigated visitors' images of the Liouhe Tourist Night Market, Kaohsiung City, Taiwan, using a scale based on the concept of cognitive and affective images. The findings showed that such images can be classified according to the following dimensions: physical setting, friendliness, representative features, entertainment, and boisterousness.

\subsection{Place Attachment}

The construct of place attachment has received a significant amount of attention in the study of individuals' bonds to a specific place (Ruiz \& Hernández, 2014). Bricker and Kerstetter (2000) suggested that place attachment entails the attribution of emotions and that it represents an individual's perceived relationship with, and functional dependence on, a specific place. They also noted that place attachment is associated with emotional identity. The use of place dependence and place identity to measure place attachment has been repeatedly verified (Williams, Patterson, Roggenbuck, \& Watson, 1992; Moore \& Graefe, 1994; Bricker \& Kerstetter, 2000; Lee \& Shen, 2013). Place dependence refers to the importance of a specific location to an individual as well as that individual's perception of strong dependence (Moore \& Graefe, 1994). Place identity refers to the perception of an environment through emotional and symbolic meanings. It represents an individual's emotional attachment to a specific place or environment (Proshansky, Fabian, \& Kaminoff, 1983). 
Regarding the relationship between destination image and place attachment, Prayag and Ryan (2012) suggested that destination image is the antecedent of destination attachment. Fan, Qiu, and Wu (2014) investigated the relationship between tourist destination image, place attachment, and tourists' environmentally responsible behavior toward tourist resorts in China. The results showed that both facility image and service image have direct effects on place dependence and that place identity is significantly affected by security image, service image, and landscape image. Based on the above, this study proposes the following hypotheses:

H1: Destination image has a significant effect on place dependence.

H2: Destination image has a significant effect on place identity.

\subsection{Destination Loyalty}

Oppermann (2000) applied the concept of loyalty to individuals' travel destination choices and called it destination loyalty. In the field of tourism and recreation, destination loyalty is an important issue to investigate (Iwasaki \& Havitz, 1998; Niininen \& Riley, 2004; Yuksel, Yuksel, \& Bilim, 2010). Loyalty can increase purchase frequency and amount, reduce cost, and create positive word-of-mouth for enterprises (Zeithaml \& Bitner, 1996).

Backman and Crompton (1991) and Dick and Basu (1994) indicated that loyalty can be divided into behavioral and attitudinal aspects. Behavioral loyalty refers to visitors' repeated participation in specific activities and use of facilities and services. Attitudinal loyalty refers to visitors' favorable attitudes toward a specific product or destination as well as the expression of intention to purchase and visit.

In previous studies, scholars have used various items to measure attitudinal loyalty. Liu, Lin, and Wang (2012) used the following four items to measure loyalty: intention to revisit, saying positive things, recommending the destination to others, and willingness to pay more. To measure loyalty to festivals, Yoon, Lee, and Lee (2010) used three items: spreading positive word-of-mouth, recommendations to friends and neighbors, and continued attendance. Yoon and Uysal (2005) used recommendations to friends/relatives and the overall desire to revisit as their two measures of destination loyalty. In addition to revisit intention and willingness to recommend, the present study uses positive word-of-mouth to investigate night market loyalty, as this measure is a significant information source that can influence users' choice of a night market destination.

With regard to the relationship between destination image and destination loyalty, Kaplanidou, Jordan, Funk, and Ridinger (2012) investigated the effect of destination image of sport tourists on place attachment and behavior intention. They found that the more positive the destination image, the higher the behavior intention. Additionally, Bosque and Martin (2008) and Mohamad, Ali, and Ghani (2011) found a positive relationship between destination image and tourist loyalty. Therefore, this study proposes the following hypothesis:

H3: Destination image has a significant effect on destination loyalty.

Regarding the relationship between place attachment and destination loyalty, Yuksel et al. (2010) demonstrated that both place dependence and place identity have a significant influence on cognitive loyalty. Additionally, Lee and Shen (2013) investigated the effect of dog walkers' leisure involvement and place attachment on destination loyalty to parks. Their results showed that both place dependence and place identity have a significant effect on destination loyalty. Therefore, this study proposes the following hypotheses:

H4: Place dependence has a significant effect on destination loyalty.

H5: Place identity has a significant effect on destination loyalty.

Figure 1 shows the conceptual model proposed in this study, as based on the research hypotheses developed in this section.

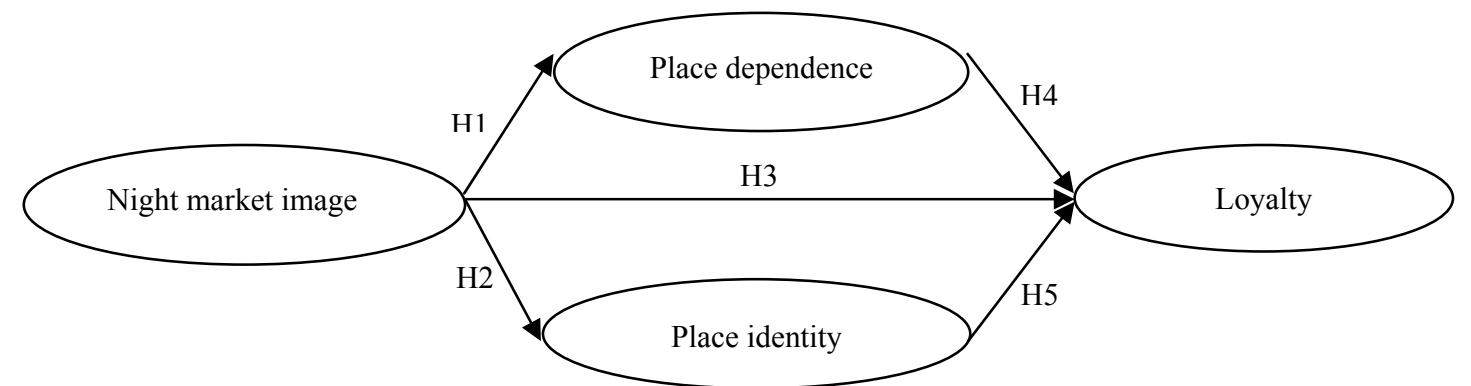

Figure 1. The conceptual model of the study 


\section{Research Methodology}

\subsection{Study Area}

Tainan City is the oldest city in Taiwan, and it has many well-known historical sites and traditional local cuisines. Therefore, night markets in Tainan City are a must-see nightlife hotspot for visitors, allowing them to appreciate the culture and delicacies of Taiwan. The most well-known night markets in Tainan City, Flower, Dadong, and Wusheng Night Markets, were selected as study areas. From the perspective of organizational development of night markets, these three night markets are permanent markets, with fixed business hours, location, and space.

\subsection{Measurement}

To measure respondents' destination image of night markets, we developed a 20 -item scale based mainly of the work of $\mathrm{Wu}(2011)$ and Lee et al. (2008). For the measurement of place attachment, we mainly referred to the scale designed by Kyle et al. (2004). Place attachment consisted of place dependence (four items) and place identity (four items). For destination loyalty, we referred to the loyalty scale designed by Yoon et al. (2010) and included three items in total. The items mentioned above were all adapted based on the characteristics of night markets. A 5-point Likert scale was used for scoring.

The survey respondents mainly included individuals who had completed their visit to any one of these three night markets and were preparing to leave. This study used a systematic sampling method (1 visitor of every 10 was sampled) to select samples and conduct a one-to-one questionnaire survey. To conform to the business hours of the studied night markets, the questionnaires were distributed and returned between 6 PM and $11 \mathrm{PM} \mathrm{pm}$, the peak business hours for the night markets, from May 21, 2015, to June 4, 2015.

A total of 500 returned questionnaires were collected from the three study night markets, but after a thorough inspection, 26 questionnaires were eliminated from this study. This left 474 questionnaires to be analyzed.

\section{Results}

\subsection{Profile of Respondents}

In terms of the demographic characteristics of the respondents, $58.4 \%$ were female, and most were unmarried (63.7\%). They were mainly between 20 and 29 years old (41.4\%), followed by the age group of 30-39 (35.1\%). Most of the respondents were college/university graduates (59.2\%). In terms of occupation, most were students $(23.30 \%)$, followed by laborers $(18.3 \%)$ and service industry workers $(17.9 \%)$. With regard to income, most of the respondents earned less than NTD 20,000 (37.2\%) per month, followed by NTD 20,001-30,000 (25.2\%). In terms of place of residence, $61.8 \%$ of the respondents lived in Tainan City, and $38.2 \%$ lived somewhere else around Taiwan. Most of the respondents had visited this night markets five to seven times (38.7\%), followed by two to four times $(25.2 \%)$, and those for whom this was the first visit $(12.6 \%)$. In terms of individual consumption, most respondents spent from NTD 201-400 (39.1\%), followed by NTD 401-600 (20.4\%). Most of the respondents visited the night market with their friends/classmates/colleague $(52.3 \%)$ or family/relatives (44.9\%).

\subsection{Confirmatory Factor Analysis of the Measurement Model}

Prior to the confirmatory factor analysis (CFA), we performed a reliability analysis and exploratory factor analysis (EFA) on the returned valid questionnaires to test whether there was internal consistency in the scales used in this study. The items with poor reliability and excessively low factor loading were deleted, and 17 items of the night market image were retained. Using EFA, these 17 items were then simplified into four factors, including characteristics/atmosphere, products/delicacies, environment/facilities, and price/bargains. The Cronbach's $\alpha$ of these four image factors ranged from $0.77-0.84$. There were no items deleted from the scales for place dependence and place identity. The Cronbach's $\alpha$ for these two constructs were 0.81 and 0.88 , respectively. The Cronbach's $\alpha$ of the loyalty scale was 0.90 . Nunnally (1978) indicated that 0.70 is the acceptable lower limit of Cronbach's $\alpha$. The reliability of the various dimensions of the scales used in this study was between 0.73 and 0.90 , which was deemed acceptable.

In this study, CFA was used to test the factor structures of various dimensions as well as convergent validity and discriminant validity. In terms of the evaluation of the recommended values of the measurement model, the factor loadings of the items in this study were from $0.60-0.94$, the SMC was from $0.36-0.88$, and the estimated parameter $\mathrm{t}$ value was greater than $1.96(\mathrm{p}<0.05)$. These met the judgment criteria of a factor loading $>0.45$, an SMC $>0.20$ (Jöreskog \& Sörbom, 1989), as shown in Table 1.

It is recommended that the values for composite reliability and average variance extracted (AVE) be greater than 0.60 and 0.50, respectively (Hair, Black, Babin, Anderson, \& Tatham, 2006; Bagozzi \& Yi, 1988). In this study, 
the composite reliability of the various dimensions was from $0.78-0.90$, and the AVE was from $0.51-0.75$, both of which met the recommended values. Based on the above, the convergent validity of the measurement model was considered acceptable, as shown in Table 1.

Table 1. Confirmatory factor analysis of the measurement model

\begin{tabular}{|c|c|c|c|c|c|}
\hline Measured variables & SFL & $\mathrm{t}$ - value & SMC & C. $\mathrm{R}$ & AVE \\
\hline Characteristics/atmosphere (C/A) & & & & 0.84 & 0.52 \\
\hline There is a bustling atmosphere. & 0.85 & & 0.72 & & \\
\hline The games are novel and interesting. & 0.66 & $14.58 * * *$ & 0.43 & & \\
\hline Vendors are friendly and passionate. & 0.69 & $15.79 * * *$ & 0.47 & & \\
\hline Featured snacks can be sampled. & 0.70 & $15.40 * * *$ & 0.49 & & \\
\hline This night market is famous. & 0.67 & $15.05 * * *$ & 0.45 & & \\
\hline Products/delicacies (P/Ds) & & & & 0.81 & 0.52 \\
\hline There are a variety of products. & 0.68 & & 0.46 & & \\
\hline The products are fashionable. & 0.60 & $11.65 * * *$ & 0.36 & & \\
\hline The products are satisfactory. & 0.76 & $13.25 * * *$ & 0.58 & & \\
\hline There are various kinds of delicacies. & 0.83 & $13.97 * * *$ & 0.68 & & \\
\hline Environment/facilities (E/F) & & & & 0.84 & 0.51 \\
\hline The environment is clean. & 0.65 & & 0.43 & & \\
\hline The food is hygienic. & 0.66 & $12.42 * * *$ & 0.44 & & \\
\hline Sufficient parking space is provided. & 0.84 & $14.14 * * *$ & 0.70 & & \\
\hline There are sufficient public facilities. & 0.66 & $12.07 * * *$ & 0.43 & & \\
\hline The night market is not overcrowded. & 0.77 & $13.43^{* * *}$ & 0.59 & & \\
\hline Price/bargains (P/B) & & & & 0.78 & 0.55 \\
\hline Prices are affordable, and quality is satisfactory. & 0.72 & & 0.51 & & \\
\hline $\begin{array}{l}\text { There are more discounts or special offers of products as } \\
\text { compared to ordinary stores. }\end{array}$ & 0.81 & $13.42 * * *$ & 0.66 & & \\
\hline Bargaining at the night market was an enjoyable experience. & 0.68 & $11.90 * * *$ & 0.45 & & \\
\hline Place dependence (PD) & & & & 0.81 & 0.52 \\
\hline $\begin{array}{l}\text { pd1 Visiting here is more important than visiting any other } \\
\text { night market. }\end{array}$ & 0.74 & & 0.55 & & \\
\hline $\begin{array}{l}\text { pd2 I would not substitute any other night market for the } \\
\text { type of recreation I do here. }\end{array}$ & 0.69 & $13.89 * * *$ & 0.47 & & \\
\hline $\begin{array}{l}\text { pd3 I enjoy visiting this night market more than any other } \\
\text { night market. }\end{array}$ & 0.72 & $14.63 * * *$ & 0.52 & & \\
\hline $\begin{array}{l}\text { pd4 I get more satisfaction from visiting this night market } \\
\text { than from visiting any other night market. }\end{array}$ & 0.73 & $14.55^{* * *}$ & 0.53 & & \\
\hline Place identity (PI) & & & & 0.88 & 0.64 \\
\hline pi1 The night market means a lot to me. & 0.84 & & 0.70 & & \\
\hline pi2 I have a special connection to this night market & 0.80 & 20.26 & 0.64 & & \\
\hline pi3 I identify strongly with this night market. & 0.84 & 20.88 & 0.70 & & \\
\hline pi4 I am very attached to this night market. & 0.73 & 17.37 & 0.53 & & \\
\hline Destination loyalty (DL) & & & & 0.90 & 0.75 \\
\hline d11 I will revisit Tainan's night market & 0.86 & & 0.74 & & \\
\hline $\mathrm{d} 22$ I will recommend other people to visit this night market. & 0.94 & 24.91 & 0.88 & & \\
\hline d13 I will say positive things about this night market. & 0.80 & 21.22 & 0.63 & & \\
\hline
\end{tabular}

$\mathrm{SD}=$ standard deviation; $\mathrm{SFL}=$ standardized factor loading; $\mathrm{SMC}=$ square multiple correlations; $\mathrm{CR}=$ composite reliability; $\mathrm{AVE}=$ average variance extracted. $\quad * * *$ denotes $\mathrm{p}<0.001$. 
In terms of the discriminant validity test, in the test of discriminant validity, Hair et al. (2006) and Fornell and Larcker (1981) indicated that the average variance extracted (AVE) for each pair of constructs should be greater than the square of the correlation between each of those two constructs. As shown in Table 2, the square root of each dimension was greater than the correlation coefficient of each dimension. The results showed that the judgment criteria were met, thus verifying that the discriminant validity of the measurement model in this study was acceptable.

Table 2. Matrix of correlation coefficients of dimensions

\begin{tabular}{|c|c|c|c|c|c|c|c|c|}
\hline \multirow{2}{*}{ Dimension } & \multirow{2}{*}{$\begin{array}{l}\text { Item } \\
\text { Number }\end{array}$} & \multicolumn{6}{|c|}{ Correlation coefficient } & \multirow[b]{2}{*}{$\mathrm{G}$} \\
\hline & & $\mathrm{A}$ & $\mathrm{B}$ & $\mathrm{C}$ & $\mathrm{D}$ & $\mathrm{E}$ & $\mathrm{F}$ & \\
\hline A. Characteristics/atmosphere & 5 & 0.72 & & & & & & \\
\hline B. Products/delicacies & 4 & $0.42^{* *}$ & 0.72 & & & & & \\
\hline C. Environment/facilities & 5 & $0.28^{* *}$ & $0.27^{* *}$ & 0.71 & & & & \\
\hline D. Price/bargains & 3 & $0.34^{* *}$ & $0.33^{* *}$ & $0.33^{* *}$ & 0.74 & & & \\
\hline E. Place dependence & 4 & $0.23^{* *}$ & $0.32^{* *}$ & $0.35^{* *}$ & $0.43^{* *}$ & 0.72 & & \\
\hline F. Place identity & 4 & $0.37^{* *}$ & $0.33^{* *}$ & $0.31^{* *}$ & $0.39^{* *}$ & $0.69^{* *}$ & 0.80 & \\
\hline G. Destination loyalty & 3 & $0.49^{* *}$ & $0.41^{* *}$ & $0.32^{* *}$ & $0.32^{* *}$ & $0.46^{* *}$ & $0.55^{* *}$ & 0.87 \\
\hline
\end{tabular}

The values on the diagonal (boldface) denote the square root of the AVE of dimensions. The values under the diagonal are standardized correlation coefficients. $\quad * *$ denotes $\mathrm{p}<0.01$.

\subsection{Evaluation of the Overall Model}

The measurement indices for the goodness-of-fit test of the hypothetical model in this study included the chi-square, normed chi-square, GFI, AGFI, RMSEA, IFI, TLI, CFI, PNFI, PCFI, and RMR. Table 4 shows the measurement indices, standards, and results of the goodness-of-fit test of the overall model. All results met the standards required for each index. Overall, the goodness of fit of this research model was found to be acceptable.

Table 4. Summary of indices of goodness of fit of the overall model

\begin{tabular}{llcccccccccc}
\hline & \multicolumn{3}{c}{ Indices of absolute fit } & \multicolumn{5}{c}{ Indices of incremental fit Indices of parsimonious fit } \\
\hline & $\begin{array}{l}\mathrm{X}^{2} \\
(\mathrm{p} \text { value })\end{array}$ & $\mathrm{X}^{2} / \mathrm{df}$ & GFI & AGFI & RMSEA & IFI & TLI & CFI & PNFI & PCFI & RMR \\
\hline $\begin{array}{l}\text { Hypothetical } \\
\text { model }\end{array}$ & $\begin{array}{l}239.37 \\
(0.00)\end{array}$ & $\begin{array}{c}2.85 \\
\mathrm{df}=84\end{array}$ & 0.93 & 0.90 & 0.06 & 0.96 & 0.95 & 0.96 & 0.75 & 0.77 & 0.03 \\
Accepted value & $\mathrm{p}>0.05$ & $<3$ & $>0.9$ & $>0.9$ & $<0.08$ & $>0.9$ & $>0.9$ & $>0.9$ & $>0.5$ & $>0.5$ & $<0.1$ \\
\hline
\end{tabular}

\subsection{Tests of Hypotheses}

In testing the research hypotheses, we used parameter estimates, positive/negative directions, and $\mathrm{p}$ values to evaluate the directions, either positive or negative, of the relationships as well as the relative strength of the effects of the variables. As shown in Figure 2, the following five hypotheses were supported: H1: destination image $\rightarrow$ place dependence (path coefficient $=0.63, \mathrm{P}<0.001$ ); H2: destination image $\rightarrow$ place identity (path coefficient $=0.65, \mathrm{P}<0.001$ ); H3: destination image $\rightarrow$ destination loyalty (path coefficient $=0.55, \mathrm{P}<0.001$ ); and H5: place identity $\rightarrow$ destination loyalty (path coefficient $=0.31, \mathrm{P}<0.01$ ). However, H4: place dependence $\rightarrow$ destination loyalty (path coefficient $=-0.07, \mathrm{P}>0.05$ ) was not supported.

In terms of direct effects, we found that destination image is a predictor affecting place dependence, place identity, and destination loyalty. Furthermore, the path coefficient of destination image to place identity $(0.65)$ was higher than that of other direct effects in this estimated structural model.

In addition to having a direct effect on destination loyalty, we also found that destination image also affects destination loyalty through place identity $(0.65 \times 0.31=0.20)$. 
The following section provides a much more detailed discussion of the relationships between destination image, place dependence, place identity, and destination loyalty.

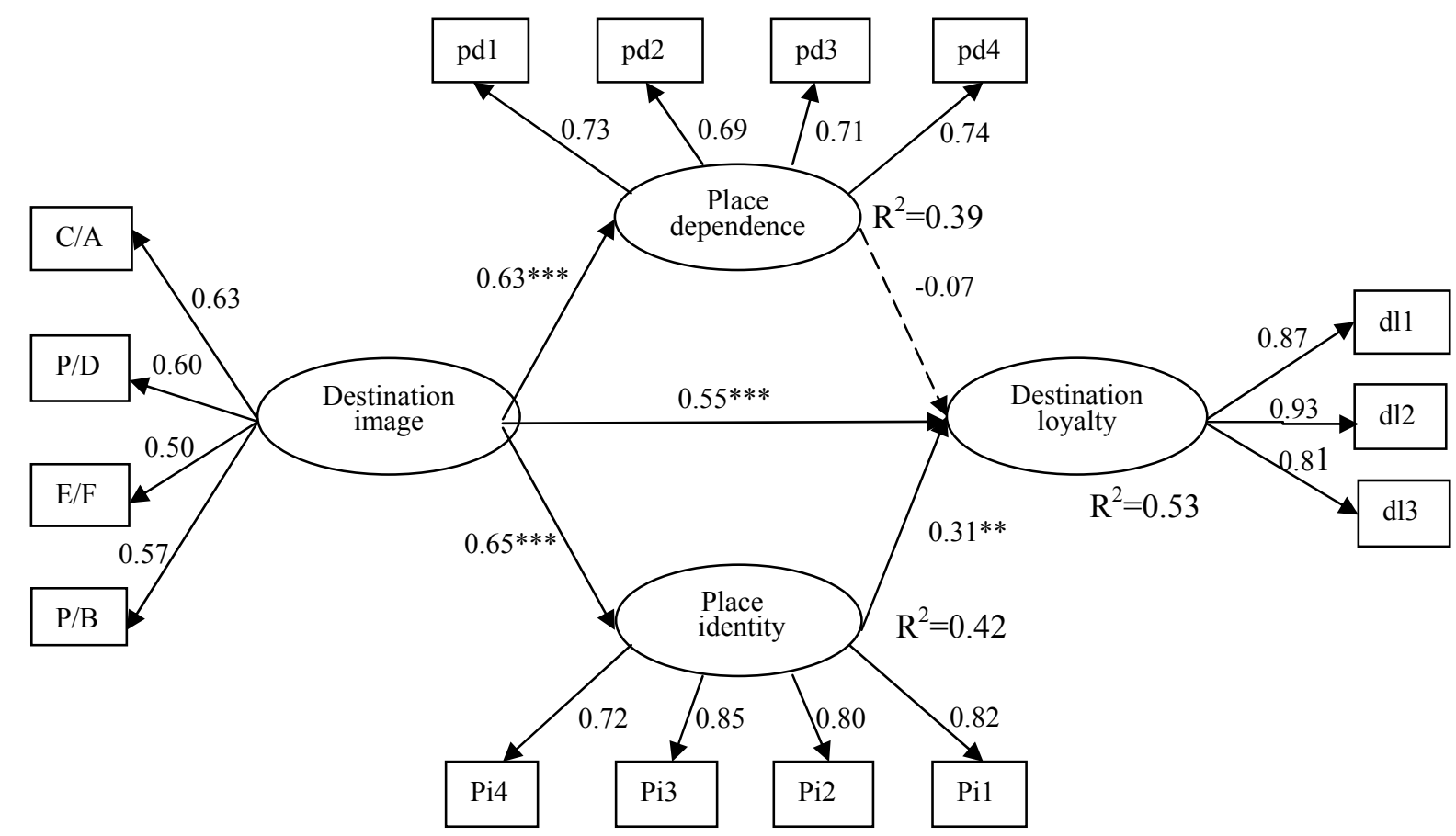

Figure 2. The estimated structural model

$\mathrm{C} / \mathrm{A}=$ characteristics/atmosphere $\mathrm{P} / \mathrm{Ds}=$ products/delicacies $; \mathrm{E} / \mathrm{F}=$ environment/facilities; $\mathrm{P} / \mathrm{B}=$ price/bargains; $\mathrm{pd}=$ place dependence; $\mathrm{pi}$ $=$ place identity; $\mathrm{dl}=$ destination loyalty.

$*=\mathrm{p}<0.05 ; * *=\mathrm{p}<0.01 ; * * *=\mathrm{p}<0.001$.

\section{Conclusion and Suggestions}

This study develops a conceptual model to verify the relationships between of destination image, place dependence, place identity, and destination loyalty among visitors in the Tainan night markets, Taiwan. In addition to clarifying the relationships between destination image, place dependence, place identity, and destination loyalty based on the cognitive model of Oliver (1980), this empirical study verified the applicability of place attachment to the investigation of the behavior of visitors to night markets.

The research result showed that, in night markets, destination image is an important antecedent of place dependence, place identity, and destination loyalty. This result was consistent with the findings of past studies, emphasizing that destination image can affect both place attachment (Wang, Weng, \& Yeh, 2011; Prayag \& Ryan, 2012) and destination loyalty (Yoon \& Uysal, 2005; Bosque \& Martin, 2008; Qu et al., 2011). Apparently, it can be inferred that maintaining a good night market image is important in order to consolidate visitors and achieve positive marketing and management outcomes.

In terms of the relationship between place attachment and destination loyalty, this study found that place identity has a direct effect on destination loyalty. However, place dependence does not have a direct effect on destination loyalty. This finding was inconsistent with the results of past studies (Alexandris et al., 2006; Yuksel et al., 2010; Lee \& Shen, 2013; López-Mosquera \& Sánchez, 2013), suggesting that both place dependence and place identity have a direct effect on destination loyalty. It may be inferred that the services provided by these three investigated night markets are somewhat similar to those provided by other night markets, and this may be the reason that the place dependence of visitors to night markets did not directly affect destination loyalty. Therefore, the weaker level of dependence on physical functionality may explain the lack of a significant effect on visitors' destination loyalty. Place identity has a direct effect on destination loyalty in this study. It can be inferred that place atmosphere, reputation, emotional-symbolic meanings, and social contacts may significantly affect loyalty in the night market context. In fact, Loureiro (2014) stressed the importance of showing visitors how the local character of a specific destination is distinct from that of other places. Chang and Hsieh (2006) also indicated 
that the value of night markets is highly correlated with the lifestyle and culture of the local residents.

In addition to having a direct effect on destination loyalty, destination image also affects destination loyalty through place identity. Therefore, when making efforts to increase destination loyalty by strengthening destination image, the effects of place identity should also be considered. Visitors' destination loyalty can be increased indirectly by deepening their emotional identity.

Based on the findings of this study, managers of these three investigated night markets are advised to proactively highlight the local atmosphere; strengthen the diversity and segmentation of product, food, and beverage selections; maintain price attractiveness; and improve the comfort, hygiene, and safety of the night market's environment and facilities. This would allow visitors to appreciate the unique features and hospitality of a specific night market in Tainan City. Such an approach may also produce an emotional/affective response among visitors, thus enhancing their memory of the market, developing a sense of identity with it, and further increasing loyalty.

In particular, several studies have shown that culinary tourism is an important marketing tool to attract people to visit a specific destination and experience local specialties (Horng \& Hu, 2009; Horng \& Tsai, 2010). Moreover, the respondents of this study held a high factor loading of an item with gastronomy-related image (there are various kinds of delicacies). To create a competitive advantage and develop the culinary and cultural image of a specific night market, management is advised to feature affordable cuisine that is both traditional and creative, reflecting local culture.

Despite its contributions, this study has certain limitations. Although these three investigated night markets are the most renowned ones in Tainan, Taiwan, the results obtained from this study may not be extendable to others in Taiwan. We suggest that follow-up studies be conducted to expand the investigation to different kinds of night markets and regions. This would shed light on any differences present across locations or organization types and enrich the understanding of the bonds people form with night markets. Additionally, our findings present only the relationships between destination image, place attachment, and destination loyalty. Follow-up studies are advised to include variables such as leisure involvement, experience, and satisfaction to shed further light on visitors' experiences at night markets. Finally, in regard to cultural aspects, follow-up studies are suggested to include foreign visitors as the sampling subjects in order to determine whether there is any difference between Taiwanese and foreign tourists in this proposed model.

\section{References}

Alexandris, K., Kouthouris, C., \& Meligdis, A. (2006). Increasing customers' loyalty in a skiing resort: The contribution of place attachment and service quality. International Journal of Contemporary Hospitality Management, 18(5), 414-425. http://dx.doi.org/10.1108/09596110610673547

Backman, S. J., \& Crompton, J. L. (1991). Differentiating between high, spurious, latent, and low loyalty participants in two leisure activities. Journal of Park and Recreation Administration, 9(2), 1-17. http://dx.doi.org/10.1080/01490408109512950

Bagozzi, R. P., \& Yi, Y. (1988). On the evaluation of structural equation models. Journal of Academic Marketing Science, 16(1), 74-94. http://dx.doi.org/10.1177/009207038801600107

Baker, D. A., \& Crompton, J. L. (2000). Quality, satisfaction and behavioral intentions. Annals of Tourism Research, 27(3), 785-804. http://dx.doi.org/10.1016/S0160-7383(99)00108-5

Baloglu, S., \& Brinberg, D. (1997). Affective images of tourism destinations. Journal of Travel Research, 35(4), 11-15.

Baloglu, S., \& McCleary, K. W. (1999). A model of destination image formation. Annals of Tourism Research, 26(4), 808-889. http://dx.doi.org/10.1016/S0160-7383(99)00030-4

Beerli, A., \& Martin, J. (2004). Factors influencing destination image. Annals of Tourism Research, 31(3), 657-681. http://dx.doi.org/10.1016/j.annals.2004.01.010

Birgit, L. (2001). Image segmentation: The case of a tourism destination. Journal of Services Marketing, 15(1), 49-66. http://dx.doi.org/10.1108/08876040110381517

Bosque, I. R., \& Martin, H. S. (2008). Tourist satisfaction: A cognitive-affective model. Annals of Tourism Research, 35(2), 551-573. http://dx.doi.org/10.1016/j.annals.2008.02.006

Bricker, K. S., \& Kerstetter, D. L. (2000). Level of specialization and place attachment: An exploratory study of whitewater recreationists. Leisure Science, 22(4), 233-257. http://dx.doi.org/10.1080/01490409950202285 
Chang, J., \& Hsieh, A. T. (2006). Leisure motives of eating out in night markets. Journal of Business Research, 59(12), 1276-1278. http://dx.doi.org/10.1016/j.jbusres.2006.10.002

Chen, C. F., \& Tsai, D. (2007). How destination image and evaluative factors affect behavioral intentions? Tourism Management, 28(4), 1115-1122. http://dx.doi.org/10.1016/j.tourman.2006.07.007

Chen, H. B., Yeh, S. S., \& Huan, T. C. (2014). Nostalgic emotion, experiential value, brand image, and consumption intentions of customers of nostalgic-themed restaurants. Journal of Business Research, 67(3), 354-360. http://dx.doi.org/10.1016/j.jbusres.2013.01.003

Choi, G. J., Tkachenko, T., \& Sil, S. (2011). On the destination image of Korea by Russian tourists. Tourism Management, 32(1), 193-194. http://dx.doi.org/10.1016/j.tourman.2009.12.002

Crompton, J. L. (1979). An assessment of the image of Mexico as a vacation destination and the influence of geographical location upon that image. Journal of Travel Research, 17(4), 18-23. http://dx.doi.org/10.1177/004728757901700404

Dadgostar, B., \& Isotalo, R. M. (1992). Factors affecting time spent by near-home tourists in city destinations. Journal of Travel Research, 31(2), 34-39. http://dx.doi.org/10.1177/004728759203100206

Dick, A. S., \& Basu, K. (1994). Customer loyalty: Toward an integrated conceptual framework. Journal of the Academy of Marketing Science, 22(2), 99-113. http://dx.doi.org/10.1177/0092070394222001

Fan, J., Qiu, H. L., \& Wu, X. F. (2014). Tourist destination image, place attachment, and tourists' environmentally responsible behavior: A case of Zhejiang tourist resorts. Tourism Tribune, 29(1), 55-66.

Fornell, C., \& Larcker, D. F. (1981). Evaluating structural equation models with unobservable variables and measurement error. Journal of Marketing Research, 18(1), 39-50. http://dx.doi.org/10.2307/3151312

Hair, J. F., Black, W. C., Babin, B. J., Anderson, R. E., \& Tatham, R. L. (2006). Multivariate data analysis (6th ed.). Upper Saddle River, NJ: Pearson Prentice Hall.

Horng, J. S., \& Tsai, C. T. (2010). Government websites for promoting East Asian culinary tourism: A cross-national analysis. Tourism Management, 31(1), 74-85. http://doi.org/10.1016/j.tourman.2009.01.009

Horng, J. S., \& Hu, M. L. (2009). The impact of creative culinary process to creative culinary performance. Journal of Hospitality, Leisure, Sport and Tourism Education, 8(2), 34-46. http://doi.org/10.3794/johlste.82.193

Huang, S. O., Liou, Y. H., \& Tzeng, G. H. (2009). Development strategies for improving the service of tourist night markets through hybrid MCDM technique. International Journal of Information Systems for Logistics and Management, 5(1), 53-68.

Iwasaki, Y., \& Havitz, M. E. (1998). A path analytic model of the relationships between involvement, psychological commitment, and loyalty. Journal of Leisure Research, 30(2), 256-280.

Jöreskog, K. G., \& Sörbom, D. (1989). LISREL 7: A guide to the program and application. Chicago: Scientific Software International.

Jorgensen, B. S., \& Stedman, R. C. (2001). Sense of place as an attitude: Lakeshore owners' attitudes toward their properties. Journal of Environmental Psychology, 21(3), 233-248. http://doi.org/10.1006/jevp.2001.0226

Kaplanidou, K., Jordan., J, Funk, D., \& Ridinger, L. (2012). Recurring Sport Events and Host Event Destination Attributes: Impact on Active Sport Tourist Behavioral Intentions. Journal of Sport Management, 26(3), 237-248. http://doi.org/10.1006/jevp.2001.0226

Kyle, G., Graefe, A., Manning, R., \& Bacon, J. (2004). Effects of place attachment on users' perceptions of social and environmental conditions in a natural setting. Journal of Environmental Psychology, 24(2), 213-225. http://doi.org/10.1016/j.jenvp.2003.12.006

Latif, R. A., \& Barua, R. (2012). Understanding the night markets' environment in Selangor, Malaysia. Interdisciplinary Journal of Contemporary Research in Business, 3(11), 668-682.

Lee, C. C. (2001). Predicting tourist attachment to destinations. Annals of Tourism Research, 28(1), 229-232. http://doi.org/10.1016/S0160-7383(00)00020-7

Lee, S. H., Chang, S. C., Hou, J. S., \& Lin, C. H. (2008). Night market experience and image of temporary residents and foreign visitors. International Journal of Culture, Tourism and Hospitality Research, 2(3), 217-233. http://doi.org/10.1108/17506180810891591 
Lee, T. H., \& Shen, Y. L. (2013). The influence of leisure involvement and place attachment on destination loyalty: Evidence from recreationists walking their dogs in urban parks. Journal of Environmental Psychology, 33, 76-85. http://doi.org/10.1016/j.jenvp.2012.11.002

Liu, C. R., Lin, W. R., \& Wang, Y. C. (2012). Relationship between self-congruity and destination loyalty: Differences between first-time and repeat visitors. Journal of Destination Marketing \& Management, 1(1-2), 118-123.

López-Mosquera, N., \& Sánchez, M. (2013). Direct and indirect effects of received benefits and place attachment in willingness to pay and loyalty in suburban natural areas. Journal of Environmental Psychology, 34, 27-35. http://doi.org/10.1016/j.jenvp.2012.11.004

Loureiro, S. M. C. (2014). The role of the rural tourism experience economy in place attachment and behavioral intentions. International Journal of Hospitality Management, 40, 1-9. http://doi.org/10.1016/j.jhm.2014.02.010

Mohamad, M., Ali, A. M., \& Ab Ghani, N. I. (2011). A structural model of destination image, tourists' satisfaction, and destination loyalty. International Journal of Business and Management Studies, 3(2), 167-177.

Moore, R. L., \& Graefe, A. R. (1994). Attachments to recreation settings: The case of rail-trail users. Leisure Sciences, 16(1), 17-31. http://doi.org/10.1080/01490409409513214

Niininen, O., \& Riley, M. (2004). Towards the conceptualization of tourism destination loyalty. Tourism Analysis, 8, 243-246. http://doi.org/10.3727/108354203774077084

Nunnally, J. C. (1978). Psychometric theory. New York: McGraw-Hill.

Oliver, R. L. (1980). A cognitive model of the antecedents and consequences of satisfaction decisions. Journal of Marketing Research, 17(4), 460-469. http://doi.org/10.2307/3150499

Oppermann, M. (2000). Tourism destination loyalty. Journal of Travel Research, 39(1), 78-84. http://doi.org/10.1177/004728750003900110

Prayag, G., \& Ryan, C. (2012). Antecedents to tourists' loyalty to Mauritius: The role and influence of destination image, place attachment, personal involvement, and satisfaction. Journal of Travel Research, 51(3), 342-356. http://doi.org/10.1177/0047287511410321

Proshansky, H. M., Fabian, A. K., \& Kaminoff, R. (1983). Place-identity: Physical world socialization of the self. Journal of Environmental Psychology, 3(1), 57-83. http://doi.org/10.1016/S0272-4944(83)80021-8

Qu, H., Kim, L. H., \& Im, H. H. (2011). A model of destination branding: Integrating the concepts of the branding and destination image. Tourism Management, 32(3), 465-476. http://doi.org/10.1016/j.tourman.2010.03.014

Ruiz, C., \& Hernández, B. (2014). Emotions and coping strategies during an episode of volcanic activity and their relations to place attachment. Journal of Environmental Psychology, 38, 279-287. http://doi.org/10.1016/j.jenvp.2014.03.008

Tourism Bureau, MOTC, Republic of China. (2015a). 2014 Survey of Travel by R.O.C Citizens. Retrieved October 21, 2014, from http://admin.taiwan.net.tw/statistics/market_en.aspx?no=16

Tourism Bureau, MOTC, Republic of China. (2015b). 2014 Annual Survey Report on Visitors Expenditure and Trends in Taiwan. Retrieved October 21, 2015, from http://admin.taiwan.net.tw/statistics/market_en.aspx?no=16

Veasna, S., Wu, W. Y., \& Huang, C. H. (2013). The impact of destination source credibility on destination satisfaction: The mediating effects of destination attachment and destination image. Tourism Management, 36, 511-526. http://doi.org/10.1016/j.tourman.2012.09.007

Wang, L. H., Weng, T. S., \& Yeh, S. S. (2011). A study of the relationship among experience value, destination image and place attachment. African Journal of Business Management, 5(26), 10869-10877. http://doi.org/10.5897/AJBM11.096

Williams, D. R., Patterson, M. E., Roggenbuck, J. W., \& Watson, A. E. (1992). Beyond the commodity metaphor: Examining emotional and symbolic attachment to place. Leisure Sciences, 14(1), 29-46. http://doi.org/10.1080/01490409209513155

$\mathrm{Wu}$, J. H. (2011). A relationship study among night market tourism image, experience satisfaction, 
post-experience behavior toward Kaohsiung Liu Ho tourist night market. Journal of Commercial Modernization, 6(2), 59-74. http://doi.org/10.6132/JCM.2011.6.2.04

Yoon, Y. S., Lee, J. S., \& Lee, C. K. (2010). Measuring festival quality and value affecting visitors' satisfaction and loyalty using a structural approach. International Journal of Hospitality Management, 29(2), 335-342. http://doi.org/10.1016/j.jhm.2009.10.002

Yoon, Y., \& Uysal, M. (2005). An examination of the effects of motivation and satisfaction on destination loyalty: Structural model. Tourism Management, 26(1), 45-56. http://doi.org/10.1016/j.tourman.2003.08.016

Yuksel, A., Yuksel, F., \& Bilim, Y. (2010). Destination attachment: Effects on customer satisfaction and cognitive, affective, and conative loyalty. Tourism Management, 31(2), 274-284. http://doi.org/10.1016/j.tourman.2009.03.007

Zeithaml, V. A., \& Bitner, M. J. (1996). Service marketing. New York: McGraw-Hill.

\section{Copyrights}

Copyright for this article is retained by the author(s), with first publication rights granted to the journal.

This is an open-access article distributed under the terms and conditions of the Creative Commons Attribution license (http://creativecommons.org/licenses/by/3.0/). 